УДК 614.253.4(09)(4)

Світлана СЕМЕНЕНКО, Лілія БОРЕЙКО, Інга ТИМОФІЙЧУК, Лілія РОМАН,

ВДНЗ України «Буковинський державний медичний університет», Чернівці (Україна)

\section{Svitlana SEMENENKO,} Liliya BOREIYKO, Inga TYMOFYYCHUK, Liliya ROMAN, Higher State Educational Establishment of Ukraine «Bukovinian State Medical University», Chernivtsi (Ukraine), physiology@bsmu.edu.ua

\author{
ІСТОРІЯ ЗАРОДЖЕННЯ ТА \\ СТАНОВЛЕННЯ \\ МЕДСЕСТРИНСТВА НА \\ БУКОВИНІ
}

\section{THE HISTORY OF ORIGIN AND \\ FORMATION OF NURSING OF BUKOVYNA}

Ключевые слова: история медсестринства Буковины, акушерская школа, медсестринские курсы, медицинские училища.
Семененко С., Борейко Л., Тимофийчук І., Роман Л. История зарождения и становления медсестринства на Буковине.

В статье исследуются этапы зарождения и становления медсестринства на территории Буковины. Медсестринство прошло сложный путь развития, который затянулся на несколько десятилетий. Исторический события, смена государств - все эти события имели однозначное влияние на все сферы общества. Голод, эпидемии, высокий уровень смертности стали мощным толчком для возникновения школ медсестринства, акушерских школ, которые длительное время были центрами медицинского образования на Буковине. Рассматриваются особенности акушерской помощи во времена Австрийской империи. Описывается «румынский период» становления медсестринства, в котором наряду с акушерскими школами создаются курсы медсестринства и появляется профессия «медицинская сестра».

Реорганизация системы здравоохранения, которая была проведена в 1944-1945гг. привела к появлению на базе обласных, городских и районних больниц курсов медицинских сестер, которые впоследствии реорганизованы в медицинские училища.

Отмечено большую роль и значительный вклад именно женщины в развитие медицины в целом и медсестринства в частности.
"Без медичних сестер немає майбутнього" - це гасло європейської конференції з сестринської справи, яка відбулася у Відні 21-28 червня 1988 р. В наш буремний час, щоб захищати Україну, на Донбас їдуть не лише солдати, а й медики. Молоді жінки віддають своє життя і здоров'я за мрію про незалежну Україну. Це люди 3 особливим внутрішнім світлом, який змусив їх обрати саме професію медсестри i, на щастя, в наших лікарнях чимало чудових медсестер, справжніх подвижниць своєї нелегкої професії ${ }^{1}$.

Мета дослідження. Визначити історичні передумови становлення та розвитку медсестринства на Буковині, підкреслити важливість історичних традицій.

Становлення та розвиток сестринської справи, як виду діяльності на Буковині бере свій початок з первіснообщинного ладу. Функції догляду та обслуговування, які входять у сферу сестринської справи, виконували жінки, матері. Цілком природно, що жінка доглядала новонароджених немовлят, дітей. Вона завжди сприяла збереженню здоров'я всіх членів сім'ї. ÏÏ турбота поширювалась на сусідів або і на всю общину. Поступово вона охоплювала радіусом своєї діяльності та опіки хворих, немічних і старих. Вико- нання функцій обслуговування походило з власного досвіду і елементарних знань, які передавали матері своїм донькам. Таким чином, уявлення про медичну сестру та її роль поєднувались з образом матері, ніжної, доброї, ласкавої, завжди близької, розумної завдяки життєвому досвіду, але неосвіченої.

3 моменту поширення християнської релігії справа обслуговування хворих та надання допомоги тим, хто іiі потребував, вважалось християнським обов'язком, проявом любові до ближнього. Повинність ця лежала на членах різних братств, черницях та ченцях (черницями називалися вдови, об'єднані в общини при монастирях). Чоловіки теж об'єднувались у релігійні братства для догляду за хворими.

В період входження земель Північної Буковини та Хотинщини до складу Київської Русі (IX-XII ст.) народних лікарів називали “лічцями”. Вони були в основному ченцями монастирів і отримували знання i лікувальні навички у спадок від батьків, прадідів, через так звані сімейні школи".

В XII-XIV ст. землі Північної Буковини та Хотинщини входили до складу Галицького та ГалицькоВолинського князівства, яке мало тісні зв'язки з країнами Європи, що давало змогу верхівці користува- 
тись медичною допомогою і надбаними знаннями. 31240 року монголо-татари встановили свою владу на землях Буковини, щ мало негативні наслідки для розвитку медичної науки і медичної допомоги. 3 середини XIV ст. на Буковину претендувало князівство Молдови, яке до 1774 року володіло цими землями аж до приходу Австрії ${ }^{2}$.

В цей складний історичний для Буковини період наукова медицина ще не стала рятівницею хворих та порадницею населення. В ті часи не було жодного навчального медичного закладу, а навчання по догляду за хворими, як і повсюди здійснювалось шляхом передачі знань на зразок ремісничого учнівства. Один iз німецьких мандрівників, що подорожував через Молдову в 1695 р. писав, що там були медикиавантюристи. А генерал фон Сплені, командувач австрійськими військами писав, що здоровя і життя людей були на останньому місці.

Починаючи 3 XVI-XVII ст. зростала кількість монастирів. На Буковині їх було побудовано 9. При монастирях створювалися лікарні, подорожні доми, які поєднували функції готелю, лікарні та амбулаторії для мандрівників, що прямували до святих місць i потребували медичної допомоги.

Починаючи з XVIII ст. на Буковині створюються лікарні, шпиталі. Так у 1776 р. в Чернівцях було відкрито пологовий будинок на 15 ліжок, а у 1779 році з'явився перший військовий шпиталь, у 1786 р. - міський шпиталь. В 1781 р. з'явилась перша військова аптека, у 1785 р. - перша аптека для цивільного населення. У 1788 р. у Чернівцях була відкрита перша лікарня у двох пристосованих приміщеннях. Догляд за хворими в першій лікарні був доручений жінкам, які за допомогою лікарів поступово оволодівали медсестринською справою. Персонал, який займався доглядом за хворими почали називати сестрами милосердя. Внаслідок особливостей політичного та соціально-економічного розвитку, формування та становлення сестринської справи відбувалось самобутнім шляхом. При такій системі підготовки медичних працівників на Буковині їх було дуже мало. В середньому одна медична сестра обслуговувала цілий повіт.

Під час панування Австро-Угорської імперії, Буковина розглядалася лише як сировинний придаток, а тому не докладалося великих зусиль в економічному та соціальному розвитку краю ${ }^{3}$.

За роки панування Австро-Угорської імперії організовано лише 7 лікарень, акушерська допомога в стаціонарах була платною. Кількість пологів коливалася в межах 5-7 \%

Перші спроби організувати лікувально-санітарну справу на Буковині відносяться до другої половини XVIII ст. Буковина на цей час входила до складу Австро-Угорської імперії.

У 1770 році уряд Австро-Угорської монархії опублікував документи:

-Головний санітарний статут;

-Патент Пергена (20.03.1773 р.)

-Указ Марії-Терези (імператриця АвстроУгорщини),

які ставили завдання уніфікувати медичну та санітарну справу імперії. У перші роки прилучення Буко- вини до Австрії, в умовах освіченого абсолютизму Марії-Терези та Йосифа II робляться спроби покращити стан лікувально-санітарної справи на Буковині.

Санітарно-медична служба, грунтуючись якоюсь мірою на наукових засадах 3 державною турботою бере початок на Буковині лише в XIX ст. На цей час припадає перше повідомлення про Чернівецьку акушерську школу, яка була першим навчальним закладом на Буковині і другим на Західній Україні, після акушерської школи Львівського університету. Подібні заклади були відкриті у Відні, Зальцбурзі, Празі та Кракові. На навчання приймали жінок віком від 18 до 40 років, від яких вимагалося лише уміння писати та читати. Кількість слухачів в перші десятиріччя Чернівецької акушерської школи була невеликою - 20-30 студентів, а вже до 1874 року школа щороку готує понад 100 дипломованих акушерок. Адміністративно школа підпорядковувалась окружному управлінню охорони здоров'я, розміщувалася в пологовому будинку, а студенти одночасно виконували дві функції: професійне навчання і практичний догляд за породіллям ${ }^{4}$.

Навчальний курс у школі тривав один семестр 3 осені до весни. Викладалися такі предмети, як терапія, філософія та практичне навчання. Останньому приділялося найбільше уваги. 31811 р. практику очолювала старша акушерка. Першою на Буковині старшою акушеркою була Марія Теодорія.

Акушерська школа перетворилася в осередок медичної освіти на Буковині. У 80 -х роках професором школи I. Волчинським було підготовлено "Проект реформування акушерської справи на Буковині", в якому наголошувалося на необхідності удосконалення професійного і духовного рівня майбутніх акушерок, їх важливості в розвитку системи рододопомоги. Виходячи 3 цього, наприкінці XIX ст. на базі акушерської школи організовуються курси підвищення акушерської кваліфікації. Незважаючи на те, що ситуація із забезпеченням Буковини акушерськими кадрами, в цілому, покращилася (кількість акушерок зросла зі 150 в 1870 р. до 300 в 1900 р.), смертність новонароджених залишилася високою - 33\%. Важливість акушерської допомоги на селі підкреслювалась і тим, що лікарів там не було, тому ті акушерки, які все ж таки залишалися працювати в сільській місцевості, користувалися серед селян особливою повагою. "Моша", як називали селяни акушерок, заробляли в середньому від 40 до 160 крон за рік ${ }^{4}$.

В квітні 1870 р. на території Західної України була створена Крайова рада здоров'я в обов'язки якої входило здійснення заходів щодо організації медичної допомоги населенню.

Наприкінці 60-х років XIX ст., із впровадженням в Росії земської медицини, в Хотинському повіті, який входив в склад Російської держави, було утворено в 6 медичних дільниць 36 лікарняними установами на 18 ліжок та 8 фельдшерськими пунктами. Лікарська допомога залишилася платною, але амбулаторні хворі отримували ліки та медичні препарати безкоштовно 5 .

В 1886 році в Чернівцях споруджена обласна клінічна лікарня, яка функціонує по цей день і була провідною установою області. 
У березні 1888 р. прийнято закон "Про організацію публічної санітарної служби в громадах воєводства Буковини". За останнім Буковина поділялася на окремі санітарні округи. 3 початком Першої світової війни на Буковині відкриваються курси милосердя, які з 1921 р. перетворилися на медичні школи ${ }^{6}$.

У румунський період відбулося становлення іншого навчального профілю - медсестринства. Системна медсестринська освіта на Буковині започаткована ще в 1914 р., коли на базі акушерської школи відкриваються курси медичних сестер. У 1921 р. курси перетворилися на окремі школи медсестер у Чернівцях, Вижниці та Косові. За австрійських часів такої професії, як "медична сестра", не існувало, проте функції медсестри виконували сестри милосердя першого та другого класів. 3 початком першої світової війни на Буковині відкриваються курси сестер милосердя, які 31929 року перетворилися на медичні школи. Відомі школи у Чернівцях, Вижниці, Косові вперше впроваджено в Радянському союзі в 1929 році ${ }^{7}$.

У Чернівцях в 30-х pp. XX ст. медична школа перебувала під патронатом "Червоного хреста" і готувала фахівців для боротьби з туберкульозом та венеричними захворюваннями.

При зарахуванні до школи абітурієнтки проходили конкурсний відбір. Навчання тривало два роки. Вивчали анатомію, патологічну анатомію, хірургію, терапію, тощо. Практичне навчання відбувалося в клініках. По закінченні кожного навчального року студенти здавали іспити з хірургії, анатомії, малої хірургії”, догляд за хворими”, гігієни, культури та ін.

Середньорічна платня сестри милосердя становила від 100 до 200 леїв (залежно від статусу та престижу клініки), лікарів -500 леїв ${ }^{8}$.

Водночас, продовжувала функціонувати акушерська школа. Порівняно з австрійським періодом" історія Чернівецької акушерської школи румунської влади" не вдалося збільшити кількість студентів, що було пов'язано із жорстокими правилами прийому до школи. Населення користувалося здебільшого засобами народної медицини, зверталося до знахарів та бабусь-повитух. На території Буковини існувало два види акушерської допомоги. Тривале співіснування на теренах України «альтернативного» акушерства 3 одного боку - в особі повитухи, 3 другого - дипломованих «акушерок», що подекуди мало характер відкритого або прихованого протистояння, дало можливість проаналізувати наслідки зіткнення традиційних та інноваційних підходів у галузі родопомочі. Варто зауважити, що негативне ставлення до повитух з боку професійний медиків було загалом традиційним. Післявоєнна відбудова сільського господарства, соціально-економічні зрушення позначилися на поступовому поверненні до нормального життя. Медики повернулися до ідеї надання допомоги породіллі через відновлення діяльності насамперед ФАПів. На це, зокрема, націлювала Постанова Президії Верховної Ради СРСР, ухвалена ще 8 червня $1944 \mathrm{p}$.

31940 p. започаткували новий етап у сфері охорони здоров'я у зв'язку з возз'єднанням Північної Буковини та Бесарабії з Україною, і створенні Чернівецької області.
На Буковині в 1944-1945 рр. була проведена реорганізація системи охорони здоровя і підготовки медичних кадрів. В 1945 році на базі обласних, міських та районних лікарень були відкриті курси медичних сестер із шестимісячним терміном навчання. Вже за перший рік було підготовлено 60 медсестер. Значний внесок у розвиток середньої медичної освіти на Буковині зробив новостворений Чернівецький медичний інститут, його науковий та кадровий потенціал. Система середньої медичної освіти в перші повоєнні роки складалася з профілюючих шкіл: фельдшерська, акушерська, фельдшерсько-акушерська, фармацевтична, зуботехнічна, школа лаборантів та школа медсестер, до яких приймалися особи віком від 15 до 35 років із неповною та повною середньою освітою. У Чернівецькій області до 1954 р. існувало три таких школи: в Чернівцях - фельдшерсько-акушерська школа і школа медсестер; у Сторожинці - школа медсестер.

В 1945-1947 pp. Чернівецькою акушерськофельдшерською школою було підготовлено 184 фельдшери-акушерки. Профілюючими предметами залишалися: терапія, акушерство, хірургія. Окрім професійних дисциплін студенти були зобов'язані вивчати такі ідеологічні предмети, як “Конституція СРСР" та "Бесіди про Червону армію".

В 1954 році прийнято рішення про створення на базі Чернівецької фельдшерсько-акушерської школи, Чернівецького медичного училища №1, а Чернівецьку школу медсестринства реорганізовано в медучилище №2, Сторожинецьку школу медсестринства - в Сторожинецьке медучилище, яке згодом було переведене у вашківці. Профілюючі школи було реорганізовано у відповідні відділення медучилищ.

Становлення та розвиток медичної допомоги, медичної освіти і медсестринства на Буковині пройшли складний історичний шлях і затягнулись на декілька десятиліть. Поневолення Галицько-Волинським князівством, князівством Молдови, Австрією, а в подальшому панування Румунії мали вплив на всі сфери суспільства. Голод, епідемії, високий рівень смертності на території Буковини стали потужним поштовхом для створення перших медсестринських шкіл, які тривалий час були осередком медичної освіти.

На сьогоднішній день важко перебільшити роль медичної сестри в системі надання медичної допомоги. Вона не тільки помічник і виконавець вказівок лікаря, вна має досить широке коло м\самостійних обов'язків. Від сумлінного виконання обов'язків медсестри залежить не тільки життя і здоровя пацієнтів, але й санітарно-епідемічне благополуччя населення.

\section{Reference:}

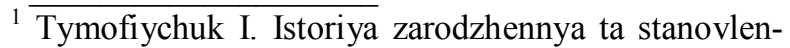
nya medsestrynstva: yevropeys'kyy kontekst / I. Tymofiychuk, S. Semepnenko, L. Roman, T. Savchuk // Aktual'ni pytannya suspil'nykh nauk ta istoriyi medytsyny. 2015. - T.8, \#4. - S. 105-109.

${ }^{2}$ Kulyk O.F. 195 rokiv Chernivets'komu medychnomu koledzhu Bukovyns'koho derzhavnoho medychnoho 
univerversytetu / O.F. Kulyk, F.V. Kuzyk, O.S. Stryzhakovs'ka // Klinichna ta eksperymental'na patolohiya. 2006. - T. 5, \# 3. - S.2-5

${ }^{3}$ Boychuk, T. M. Istoriya rozvytku akusherstva ta hinekolohiyi na Pivnichniy Bukovyni [Tekst] / T. M. Boychuk, I. D. Shkrobanets', O. M. Yuz'ko, O. A. Andriyets', I. R.Nitsovych // Neonatolohiya, khirurhiya ta perynatal'na medytsyna. - 2013. - \# 4 (10). - S. 153-159.

${ }^{4}$ Bilous, V. I. Narysy z istoriyi medytsyny ta farmatsiyi $v$ pytannyakh i vidpovidyakh vid pervisnykh do novykh chasiv (z elementamy medychnoyi etyky i deontolohiyi) [Tekst] / V. I. Bilous, V. V. Bilous, M. I. Hrytsyuk, T. M. Vorotnyak; za red. V. E. Kardasha. - Chernivtsi, 2010. $132 \mathrm{~s}$.

${ }^{5}$ Kobylyans'kyy, S. D. Istoriya medytsyny Bukovyny. Tsyfry y fakty / S. D. Kobylyans'kyy, V. P. Pishak, B. Ya. Drobnis. - Chernivtsi: Vydavnytstvo BDMA, 1999. $-249 \mathrm{~s}$.

${ }^{6}$ Pol'ova, S. P. Rozvytok akushers'koyi sluzhby Pivnichnoyi Bukovyny [Tekst] / S. P. Pol'ova, I. R. Nitsovych // Klinichna anatomiya ta operatyvna khirurhiya. - 2009. T. 8, \# 4. - S. 91-96.

${ }^{7}$ Parayko K. V. Istoriya profesiynoyi akushers'koyi dopomohy na terytoriyi Bukovyny (II pol. XVIII - 70-ti rr. KhKh st.) / K.V. Parayko // Scientific Journal «ScienceRise». - 2015. - T.7, \#2. - 46-51

8 Yuz'ko, O. M. Istoriya kafedry akusherstva i hinekolohiyi z kurrsom dytyachoyi ta pidlitkovoyi hinekolohiyi Bukovyns'koyi derzhavnoyi medychnoyi akademiyi. [Tekst] / O. M. Yuz'ko // Klinichna anatomiya ta operatyvna khirurhiya. - 2003. - T. 2, \# 4. - S. 76-82.

${ }^{9}$ Rusnak, O. Likarnyana sluzhba Pivnichnoyi Bukovyny i Khotynshchyny u mizhvoyennyy period [Tekst] / O. Rusnak // Nauka i osvita: krok u maybutnye. Materialy VI Mizhnarodnoyi naukovoyi konferentsiyi «Kayndlivs'ki chytannya», prysvyachen 145-richchyu vid dnya narodzhennya R. F. Kaynd-lya. - Chernivtsi-Vyzhnytsya: Cheremosh, 2011. - S. 461-464.

Semenenko S., Boreiyko L., Tymofyychuk I., Roman L. The history of origin and formation of nursing of Bucovyna. The article examines the stages of the origin and formation of nursing. Nursing has passed a complex way of development which was tightened for some decades. Historical events, change of the states - all these events had unequivocal influence on all spheres of a society. Famine, epidemics, a high death rate became a powerful push for occurrence of schools the nurse schools which long time were the centers of medical education on Bukovina. Features obstetrical schools the help in days of the Austrian empire are considered.

«The Romanian period» becoming the nurse in which alongside with obstetrical schools rates the nurse are created is described and there is a trade «the medical sister».

Reorganization of system of public health services which has been lead (has been carried out) in 1944-1945гг. has led to to occurrence on base of city hospitals of rates of medical sisters which subsequently are reorganized in medical schools.

The article shows difficult times, conflict and difficult conditions in which the foundations of modern nursing were formed. There has been noted a big role and a significant contribution of women to the development of medicine in general and nursing in particular.

Key words: History of nursing Bukovina, obstetrical school, nursing rates, nursing schools/

Семененко Світлана - кандидат біологічних наук доиент кафедри фізіології ім. Я. Кірменблата ВДНЗ України "Буковинський державний медичний університет". Співавтор монографії та 2 підручників. Автор 55 наукових статей. Наукові інтереси: роль оксиду азоту в хроноритмічній регуляиії діяльності нирок.

Semenenko Svetlana - candidate of biological sciences. Associate professor of physiology department named after $Y$. Kirshenblata of Higher State Educational Establishment of Ukraine «Bukovinian State Medical University». Co-author of monograph and two textbooks. The author of 55 scientific publications. Research interests: the role of nitric oxide in the regulation of renal chronorytmichniy of kidney.

Борейко Лілія - кандидат медичних наук, доцент кафедри догляду за хворими та вищої мед сестринської освіти, ВДНЗ Украӥни "Буковинський державний медичний університет”. Коло наукових інтересів: історія медииини, медсестринства, догляд за хворими. Автор понад 60 наукових праиь.

Boreiyko Liliya - candidate of medical science, assistant of professor of Higher State Educational Establishment of Ukraine «Bukovinian State Medical University». Co-author of two books and of over 60 scientific articles. Research interests: history of medicine, care of patients, the nurse,

Тимофійчук Інга - кандидат медичних наук, доцент кафедри фізіології ВДНЗ України “Буковинський державний медичний університет”. Співавтор 2 підручників й автор понад 70 наукових статтей. Коло наукових інтересів: вплив патогенних чинників на структуру $i$ функиію нервової системи людини.

Tymofiychuk Inga - candidate of medical science, assistant professor of physiology of Higher State Educational Establishment of Ukraine "Bukovinian State Medical University». Co -author of two text-books and of over 70 scientific articles. Research interests: pathogenic factors influence on the structure and function of the human nervous system.

Роман Лілія - кандидат філологічних наук, викладач кафедри суспільних наук та українознавства ВДНЗ України «Буковинський державний медичний університет». Автор понад 60 публічистичних та 32 наукових і навчальнометодичних робіт. Співавтор навчально-методичного підручника та монографії. Коло наукових інтересів: інновації у методииі викладання української мови як іноземної, порівняльна граматика та стилістика української та англійської мов, нейролінгвістика, психолінгвістика.

Roman Liliya - PhD of Philology, teacher of the department of Social Sciences and Ukrainian Studies of Higher State Educational Establishment of Ukraine "Bukovinian State Medical University". Author of more than 60 nonfiction and 32 scientific and educational works. Coathour of teaching textbook and monograph. Research interests: innovationin methods of teaching Ukrainian as a foreign language, comparative grammar and style of Ukrainian and English languages, neurolinguistics, psycholinguistics.

Received: 22-06-2016

Advance Acces Publischer: July 2016

(C) S. Semenenko, L. Boreiyko, I. Tymofiychuk, L. Roman, 2016 